\title{
PENGARUH STRES KERJA DAN LINGKUNGAN KERJA TERHADAP TURNOVER ITENTION PADA KARYAWAN OPPO KOTA BIMA
}

Ainayah Oksa Dwiyanthi

Sekolah Tinggi Ilmu Ekonomi (STIE) Bima

email: ayiknayahstiebima16@gmail.com

Muhammad Yusuf

Sekolah Tinggi Ilmu Ekonomi (STIE) Bima

email: yusufzm.stiebima@gmail.com

\begin{abstract}
This study aims to determine and analyze the effect of work stress and the environment on turnover attention of employees of Oppo Kota Bima. The type of research used is associative, with a sample of 35 respondents. The sampling technique used was purposive sampling. Data collection using a questionnaire with a Likert scale. The data analysis method used is validity test, reliability test, simple linear regression, simple correlation, determination test and test (two parties). The results of this study conclude that the workload has an influence on the work environment of the Bima City oppo employees, where the $t$ value of 8.325 is greater than the table value of 2.036 $(8.325>2.036)$ with a significant value of 0.000 less than $0.05(0,000,0,05)$.
\end{abstract}

Keywords : work stress, work environment and turnover intention

\begin{abstract}
Abstrak
Penelitian ini bertujuan untuk mengetahui dan menganalisis pengaruh stress kerja dan lingkungan terhadap turnover itention pegawai oppo kota bima. Jenis penelitian yang digunakan adalah asosiatif, dengan sampel sebanyak 35 responden. Teknik sampling yang di guanakan adalah purposive sampling. Pengumpulan data menguanakan kuesioner dengan skala likert. Metode analisis data yang digunakan adalah uji validitas, uji reabilitas, regresi linear sederhana, korelasi sederhana, uji determinasi dan uji $t$ (dua pihak). Hasil dari penelitian ini menyimpulkan bahwa beban kerja mempunyai pengaruh terhadap lingkungan kerja pada pegawai oppo kota bima, dimana nilai $t$ hitung sebesar 8,325 lebih besar dari nilai t tabel sebesar 2,036 ( 8,325 > 2,036) dengan nilai signifikan sebesar 0,000 lebih kecil dari 0,05 (0,000,0,05).
\end{abstract}

Kata Kunci: Stress kerja, lingkungan kerja dan turnover intention 


\section{PENDAHULUAN}

Salah satu yang menjadi masalah dalam sebuah perusahaan terutama era globalisasi adalah tingkat kerja turnover yang tinggi. Turnover atau pergantian tenaga kerja dalam sebuah perusahaan adalah sebuah bentuk yang nyata dari sebuah turnover intention yang dapat menjadi masalah yang serius bagi perusahaan. Robbins (2012).

Turn over intention adalah sebuah keinginan dari individu dalam merubah pekerjaannya untuk melakukan pergantian tenaga kerja. Sedangkan pengertian lain mengenai turnover intention disampaikan oleh mathis dan Jackson (2011) mengemukakan turnover intention adalah suatu proses ketika karyawan meninggalkan suatu organisasi dan meninggalkan suatu posisi pekerjaan dan dimana posisi tersebut harus $\mathrm{d}$ gantikan oleh orang lain.

Indikasi lain yang mempengaruhi turnover intention adalah lingkungan keja. Lingkungan kerja adaalah factorfaktor diluar dari karyawan dapat berupa fisik ataupun non fisik dalam sebuah perusahaan. Perusahaan harus memperhatikan lingkungan kerjanya agar dapat menciptakan suasana yang kondusif sehingga dapat melancarkan jalannya pekerjaan para karyawan menurut staffelbach (2008). Oleh karena itu, perusahaan harus sangat memperhatikan lingkungan kerja agar semua karyawannya merasa nyaman dalam menyelesaikan semua pekerjaan yang di berikan.

Oppo adalah produsen elektronik, perusahaan ini telah terdaftar dengan nama merk oppo dibelahan dunia. Oppo terknal dengan seri pertamanya yaitu oppo find 5. Dan menduduki peringkat ke-4 merk smartphone diseluruh dunia pada tahun 2017, dan merupakan merk smartphone nomor 1 di china pada tahun
2016. Smartphone berjenis oppo sekrang bukan hanya sebagai penunjang kebutuhan untuk berkomunikasi saja, namun banyak fungsi lain seperti untuk bermain game dan masih banyak fungsi lainnya dengan banyak dukungan nya dari pengembang aplikasi smartphone tersebut.

Oppo termasuk rising star di pasar seluler Indonesia. Baru satu tahun berkiprah di sini, pangsa pasarnya sudah tergolong tinggi. Volume penjualannya diyakini telah lebih besar dibandingkan LG, Sony, dan beberapa merek global lain.

Masalah yang terjadi Karyawan dituntut untuk mampu menyelesaikan tugas dan tanggung jawabnya secara efektif dan efisien. Keberhasilan karyawan dalam bekerja dapat dinilai dari kepuasan konsumen, dan berkurangnya jumlah keluhan konsumen. Kinerja karyawan juga dapat diukur dari cepat atau tidaknya karyawan dalam menjalankan tugas dan tanggung jawabnya, serta melakukan peran dan fungsinya yang berhubungan positif bagi keberhasilan perusahaan.

Terdapat faktor negatif yang dapat menurunkan kinerja karyawan, diantaranya adalah menurunnya keinginan karyawan untuk mencapai prestasi kerja, kurangnya ketepatan waktu dalam bekerja, dan juga seringnya melanggar peraturan perusahaan, pengaruh yang berasal dari lingkungan kerjanya, teman sekerja yang menurun semangatnya dalam bekerja, dan tidak adanya contoh yang harus dijadikan acuan dalam pencapaian prestasi kerja yang baik. Semua itu merupakan penyebab menurunnya kinerja karyawan dalam bekerja. 
Turnover intention (intense keluar) adalah kecendrungan atau niat karyawan untuk berhenti bekerja dari pekerjaannya (witasari 2009) menguraikan turnover intention merupakan kemungkinan yang bersifat subjektif dimana seseorang individu akan merubah pekerjaannya dalam jangka waktu tertentu.

Harnoto (2002) menyatakan: turnover itentions adalah kadar atau intensitas dari keinginan untuk keluar dari perusahaan, banyak alasan yang menyebabkan timbulnya turnover itentons ini diantaranya adalah keinginan untuk mendapatkan pekerjaan yang lebih baik.

\section{TINJAUAN PUSTAKA}

\subsection{Stress Kerja}

Handoko (2010) mendefinisikan stress sebagai suatu kondisi ketegangan yang mempengaruhi emosi, proses berpikir dan kondisi seseorang. Stress yang berlebihan akan berdampak pada hasil kerja seseorang dalam organisasi.

Kreittner dan Kinciki (2005) mendefinisikan stress sebagai respon adaptif dan dihubungkan oleh karakteristik dan atau proses psikologis individu, yang merupakan suatu konsekuensi dari setiap tindakan eksternal, situasi atau peristiwa yang menempatkan tuntutan piskologis/fisik khusus pada seseorang.

\subsection{Lingkungan Kerja}

Menurut sunyoto (2012) bahwa lingkungan kerja adalah segala sesuatu yang ada disekitar para pekerja dan yang dapat mempengaruhi dirinya dalam menjalankan tugas-tugas yang $\mathrm{di}$ bebankan. Menurut Nitisemito (2000) lingkungan kerja adalah sesuatu yang ada disekitar para pekerja yang dapat mempengaruhi dirinya dalam menjalankan tugas-tugas yang diembankan. Indikator lingkungan kerja : menurut Sedarmayanti (2011) yaitu : 1). penerangan 2). suhu udara 3). suara bising 4). penggunaan warna 5). ruang gerak yang diperlukan

\subsection{Turnover Itention}

Turnover intention (intense keluar) adalah kecendrungan atau niat karyawan untuk berhenti bekerja dari pekerjaannya (witasari 2009) menguraikan turnover intention merupakan kemungkinan yang bersifat subjektif dimana seseorang individu akan merubah pekerjaannya dalam jangka waktu tertentu.

Harnoto (2002) menyatakan : turnover itentions adalah kadar atau intensitas dari keinginan untuk keluar dari perusahaan, banyak alasan yang menyebabkan timbulnya turnover itentons ini diantaranya adalah keinginan untuk mendapatkan pekerjaan yang lebih baik Indikator turnover itention : menurut Mobley (2011) yaitu : 1). pikiran-pikiran untuk berhenti. 2). keinginan untuk meninggalkan 3). keinginan untuk mencari pekerjaan lain.

\section{METODE PENELITIAN}

\subsection{Jenis Penelitia}

Jenis penelitian ini termasuk penelitian asosiatif.Penelitian asosiatif merupakan suatu penelitian yang bertujuan untuk mengetahui tentang pengaruh ataupun hubungan antara dua variabel atau lebih (Sugiyono, 2012:26).

\subsection{Populasi, Sampel Penelitian, Dan Sampling Penelitian}

a. Populasi

Menurut Sugiono (2016:80) Populasi adalah wilayah generalisasi yang terdiri atas, obyek/subyek yang mempunyai kualitas dan karakteristik tertentu yang ditetapkan oleh peneliti untuk dipelajari dan kemudian ditarik 
kesimpulannya. Adapun populasi yang digunakan yaitu 100 orang karyawan yang bekerja pada Oppo Kota Bima

b. Sampel penelitian

$$
\text { Menurut Sugiono (2016:81) }
$$

Sampel adalah bagian dari jumlah karakteristik yang dimiliki oleh populasi tersebut. Sampel dalam penelitian ini yaitu sebanyak 35 orang karyawan Oppo bagian pemasaran dengan menggunakan tehnik porposive sampling.

c. Instrumen Penelitian Dan Teknik Pengumpulan Data

Dalam penelitian ini untuk mengukur variabel bebas dan terikat maka digunakan kuesioner yang bersifat tertutup dimana responden deberi alternative pilihan jawaban pada setiap pernyataan. Kuesioner dibagikan pada sejumlah responden, dan seluru aitem variabel akan diukur mengunakan skala likert sebagai berikut:

- Jawaban sangat setuju akan diberi skor 5

- Jawaban setuju diberi skor 4

- Jawaban netral diberi skor 3

- Jawaban tidak setuju diberi bobot 2

- Jawaban sagat tidak setuju diberi skor 1

\subsection{Teknik pengumpulan data}

1. Observasi

Observasi dalah metode pengumpulan data yang dilakukan dengan pengamatan secara langsung di lapagan atau lokasi yang menjadi tempat penelitian.

\section{Wawacara}

Wawancara adalah proses dialog bersama narasumber ntuk memperoleh keterangan terkait tentang masalah yang diteliti.

3. Angket/kuesioner

Yaitu sekumpulan daftar pertanyaan/pernyataan yang di ajukan kepada responden untuk memperoleh data-data setra informasi yang dibutuhkan.
4. Studi pustaka

Merupakan pengumpulan data penelitian dengan menggunakan berbagai macam bentuk penelitian misalya buku, jurnal, ataupun penelitian terdahulu sebagai acuan dalampenelitian.

\subsection{Lokasi Penelitian}

Penelitian ini dilakukan pada kantor oppo cabang bima JL.soekarno hatta

\subsection{Teknik Analisis Data}

\section{Uji validitas dan Uji reabilitas}

a. uji validitas

Menurut Sugiyono (2016:177) menunjukan derajat ketepatan antara data yang sesungguhnya terjadi pada objek dengan data yang dikumpulkan oleh peneliti untuk mencari validitas sebuah item, kita mengkorelasikan skor item dengan total item-item tersebut.

b. Uji reliabilitas

Menurut Imam Ghozali (2013) Reliabilitas berhubungan dengan kepercayaan masyarakat.Reliabilitas merupakan alat untuk mengukur suatu daftar pertanyaan koisioner yang merupakan indikator dari variabelvariabel yang diteliti.Uji reliabilitas dilakukan terhadap item pertanyaan yang dinyatakan valid.

\section{Uji asumsi klasik}

a. Uji nomalitas

Menurut Imam Ghozali (2013:110), tujuan dari uji normalitas adalah untuk mengetahui apakah masing-masing variabel berdistribusi normal atau tidak.

b. Uji heteroskesdastis

Menurut Iman Ghozali (2013:205), uji heteroskesdastisitas bertujuan untuk menguji apakah dalam model regresi terjadi ketidaksamaan varians dari residual satu pengamatan ke pengamatan lain tetap, maka disebut 
heteroskedastisitas dan jika berbeda disebut tidak heteroskesdastisitas.

c. Uji multikolonieritas

Bertujuan untuk menguji apakah dalam ,odel regresi ditemukan adanya korelasi antara variabel independen. Untuk menguji multikolonieritas dilakukan dengan melihat (1) Nilai tolerance (TOL) dan lawannya (2) varience Inflation factor (VIP)

d. Uji autokorelasi

Menurut Imam Ghozali (2013:110) uiji autokorelasi bertujuan untuk menguji apakah dalam model regrresi ada korelasi anatara kesalahan pengganggu pada periode $t$ dengan kesalahan penngganggu pada periode $\mathrm{t}-1$ (sebelumnya)

e. Regresi Linear Berganda

Analisis yang digunakan dalam penelitian ini adalah analisis regresi berganda yaitu model regresi untuk menganalisis lebih dari satu variabel independen

\section{f. Uji Koefisien Determinasi \\ Koefisien determinasi}

digunakan untuk mengetahui presentasi variabel independen secara bersama sama dapat menjelaskan variabel dependen. Nilai koefisien determinasi adalah antara nol dan satu. Jika koefisien determinasi $\left(R^{2}\right)=1$, artinya variabel independent memberikan semua informasi yang dibutuhkan untuk memprediksi variasi variabel dependen. Jika koefisisen determinasi $\left(\mathrm{R}^{2}\right)=0$, artinya variabel independen tidak mampu menjelaskan variasi variabel dependen dengan menggunakan bantuan SPSS.

\section{g. Uji koefesien korelasi}

Korelasi Berganda adalah suatu korelasi yang bermaksud untuk melihat

- Jika t hitung lebih besar dari t tabel pada tingkat kepercayaan $95 \%$ atau hubungan antara 3 atau lebih variabel (dua atau lebih variabel dependent dan satu variabel independent).

h. Uji Simultan (Uji F)

Uji simultan dengan $\mathrm{F}$ testini pada dasarnya bertujuan untuk mengetahui pengaruh bersama-sama variabel independen terhadap variabel dependen.Pengujian $\mathrm{F}$ dilakukan dengan membandingkan $\mathrm{F}$ hitung dengan $\mathrm{F}$ table .Jika $\mathrm{F}$ hitung lebih besar dari $\mathrm{F}$ tabel dengan tingkat kepercayaan $95 \%$ atau (p-value<0,05),maka Ha diterima, yang artinya variabel independen yang diuji secara bersama-sama mempunyai pengaruh terhadap variabel dependen.

Uji statistik $F$ pada dasarnya menunjukkan apakah semua variabel bebas yang dimasukkan dalam model mempunyai pengaruh secara bersamasama terhadap variabel terikat (dependent).Kriteria pengambilan keputusan adalah (Ghozali, 2005).

- Bila F hitung > F tabel atau probabilitas $<$ nilai signifikan $(\leq 0,05)$,maka hipotesis tidak dapat ditolak, ini berarti bahwa secara simultan variabel independent memiliki pengaruh signifikan terhadap variabel dependent.

- Bila F hitung $<$ F tabel atau probabilitas $>$ nilai signifikan $(\operatorname{Sig} \geq 0,05)$,maka hipotesis diterima, ini berarti secara simultan variabel independen tidak mempunyai pengaruh signifikan terhadap variabel dependent.

- Uji parsial (uji t) Uji parsial dengan t test ini bertujuan untuk mengetahui besarnya pengaruh masing-masing variabel independent secara individu (Parsial) terhadap variabel dependen. Pengujian $t$ dilakukan dengan membandingkan $t$ hitung dengan $t$ tabel.

(p- value<0,05),maka Ha diterima,yang artinya variabel independen yang diuji 
secaraparsial mempunyai pengaruh

\section{HASIL DAN PEMBAHASAN}

\section{Uji Asumsi Klasik}

a. Uji Normalitas

Normalitas P-P Plot Of Regression Standardized Residual

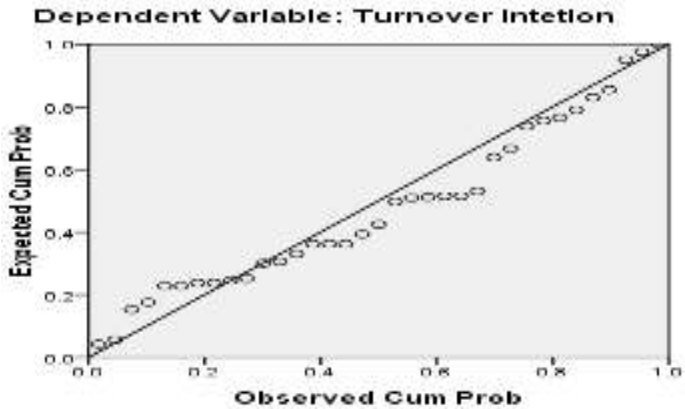

Sebagai mana terlihat dalam grafik normal P-P plot of regression Standardized Residual, terlihat bahwa titik-titik menyebar disekitar garis diagonal, serta menyebrang mengikuti arah garis diagonal (membentuk garis lurus), maka dapat dikatakan bahwa data distribusi normal dan model regres layak dipakai untuk memprediksi kinerja karyawan bedasarkan variabel bebasnya.

b. Uji Heterokedastisitas Beatterpiot

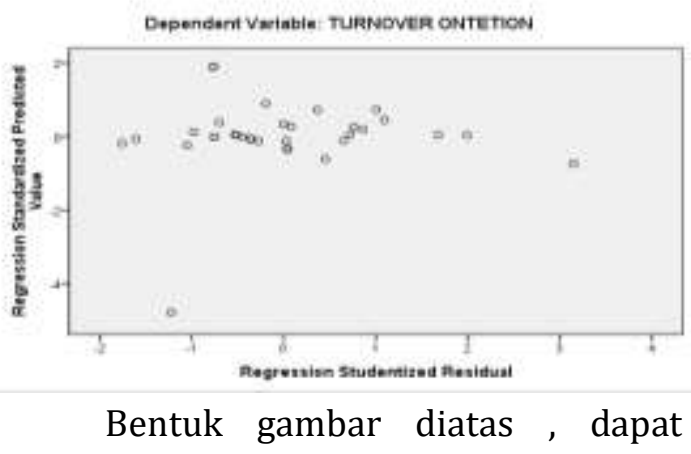
dilihat bahwa penyebaran residual adalah tidak teratur dan tidak membentuk pola. Hal tersebut dapat dilihat pada titik-titik atau plot yang menyebar. Kesimpulan yang dapat diambil adalah bahwa tidak terjadi residual. Dari hasil pengujian dengan metode VIF terlihat bahwa nilai tolerance $>0,725$ dan nilai VIF $<10,00$ terhadap variabel dependent maka dapat disimpulkan bahwa tidak terjadi multikolinieritas

c. Uji autokorelasi

Model Summary

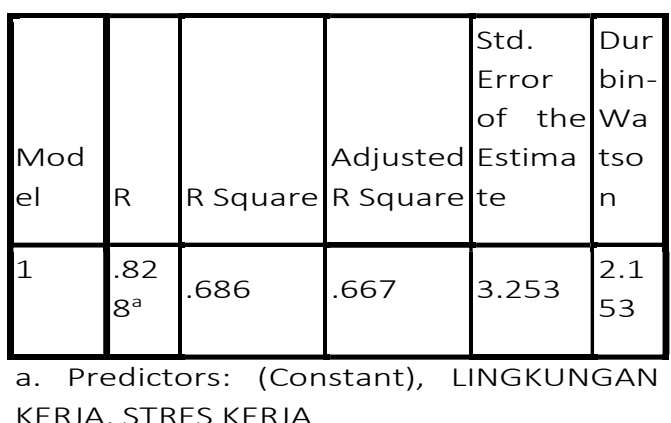

KERJA, STRES KERJA

b. Dependent Variable: TURNOVER ONTETION

Bedasarkan tabel di atas didapat nilai DW sebesar 2.153. oleh karena pengambilan keputusan sebagaimana dasar keputusan dalam uji DurbinWatson di atas, maka dapat ditarik kesimpulan bahwa tidak terdapat masalah atau gejala autokorel.

\section{Analisis regresi linier berganda}

Nilai konstanta bernilai positif sebesar 24,633 hal ini menunjukkan apabila variabel stres kerja dan lingkungan kerja bernilai nol, maka turnover intetion sebesar 24,633.

Coefficients $^{\mathrm{a}}$

\begin{tabular}{|c|c|c|c|c|c|c|c|}
\hline \multirow[b]{2}{*}{ Model } & \multicolumn{2}{|c|}{$\begin{array}{l}\text { Unstandardized } \\
\text { Coefficients }\end{array}$} & \multirow{2}{*}{\begin{tabular}{|l|}
$\begin{array}{l}\text { Standardized } \\
\text { Coefficients }\end{array}$ \\
Beta
\end{tabular}} & \multirow[b]{2}{*}{$t$} & \multirow[b]{2}{*}{ Sig. } & \multicolumn{2}{|c|}{$\begin{array}{l}\text { Collinearity } \\
\text { Statistics }\end{array}$} \\
\hline & B & Std. Error & & & & Tolerance & VIF \\
\hline (Constant) & 24.633 & 4.395 & & 5.605 & .000 & & \\
\hline $\begin{array}{l}\text { STRES } \\
\text { KERJA }\end{array}$ & -.775 & .153 & -.588 & -5.053 & .000 & .725 & 1.378 \\
\hline $\begin{array}{l}\text { LINGKUNG } \\
\text { AN KERJA }\end{array}$ & 1.049 & .126 & .968 & 8.325 & .000 & .725 & 1.378 \\
\hline
\end{tabular}

a. Koefisien regresi variabel stres kerja bernilai positif sebesar -0.775 hal ini menunjukkan bahwa apa bila stres kerja semakin baik dengan asumsi variabel lain konstan, maka hal 
tersebut dapat meningkatkan turnover intetion sebesar -0.775

b. Koefisien regresi variabel lingkungan kerja bernilai positif sebesar 1.049, hal ini menunjukkan apabila variabel lingkungan kerja semakin baik dengan asumsi variabel lain konstan, maka hal tersebut dapat meningkatkan turnover intetion sebesar 1.049

\section{Analisis koefesien determinasi}

\section{Model Summaryb}

\begin{tabular}{|l|l|l|l|l|l|}
\hline & & & $\begin{array}{l}\text { Adjust } \\
\text { ed }\end{array}$ & $\begin{array}{l}\text { Std. } \\
\text { Error } \\
\text { of the }\end{array}$ & $\begin{array}{l}\text { Durb } \\
\text { in- } \\
\text { Mode } \\
\mathrm{l}\end{array}$ \\
\hline 1 & $\mathrm{R}$ & $\begin{array}{l}\text { Squar } \\
\text { e }\end{array}$ & $\begin{array}{l}\text { Squar } \\
\text { e }\end{array}$ & $\begin{array}{l}\text { Estima } \\
\text { te }\end{array}$ & $\begin{array}{l}\text { Wats } \\
\text { on }\end{array}$ \\
\hline 1 & $828 \mathrm{a}$ & .686 & .667 & 3.253 & $\begin{array}{l}2.15 \\
3\end{array}$ \\
\hline
\end{tabular}

a. Predictors: (Constant), LINGKUNGAN KERJA, STRES KERJA

b. Dependent Variable: TURNOVER ONTETION

Dari data diatas, dapat diketahui bahwa koefisien determinasi (R Square) yang diperoleh sebesar 0,685. Hal ini menunjukkan bahwa variabel stres kerja dan lingkungan kerja hanya mempengaruhi sebesar $68,6 \%$ terhadap turnover intetion. Sedangkan sisanya 31,4\% dipengaruhi oleh variabel lain yang tidak diteliti dalam penelitian ini.

Model Summary ${ }^{b}$

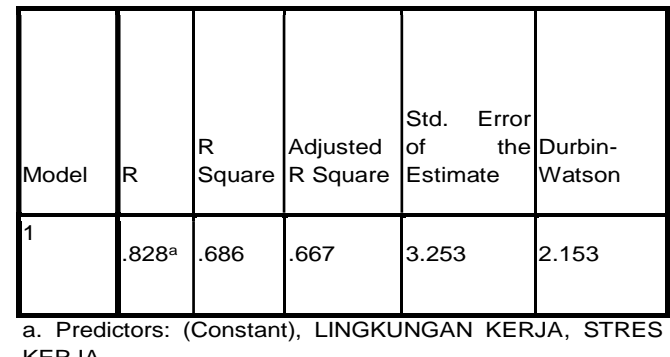

b. Dependent Variable: TURNOVER ONTETION

\section{Analisis koefesien korelasi}

Dari data diatas, dapat diketahui bahwa koefisien korelasi(R) yang diperoleh sebesar 0,828. Hal ini menunjukkan hubungan variabel stres kerja dan lingkungan kerja sebesar 82,8\% terhadap turnover intetion. Sedangkan sisanya $17,2 \%$ dipengaruhi oleh variabel lain yang tidak diteliti dalam penelitian ini.

\begin{tabular}{|l|c}
\hline Interval koefisien & Tingkat hubungan \\
$0,00-0,199$ & Sangat rendah \\
$0,40-0,599$ & Rendah \\
$0,60-0,799$ & Sedang \\
$0,80-1,000$ & Kuat \\
\end{tabular}

\section{Uji Simultan (Uji F)}

Dari uji ANOVA atau $F$ test diperoleh $F_{\text {hitung }}$ sebesar 34,978. Untuk menentukan $\mathrm{F}_{\text {tabel }}$ digunakan lampiran statistika $F_{\text {tabel }}$ dengan menggunakan $\alpha=$ $5 \%$. Nilai df1 (jumlah variabel - 1) atau 3 - 1 = 2 dan df2 (n-k-1) atau 35-2 - $1=$ 32. Maka diperoleh $F_{\text {tabel }}$ sebesar 3,295. Hal ini mengartikan bahwasanya nilai $\mathrm{F}$ hitung $>F_{\text {tabel }}$ yaitu $34,978>3,395$ sehingga $\mathrm{H}_{0}$ di tolak dan $\mathrm{H}_{\mathrm{a}}$ diterima. Yang berarti variabel stres kerja dan lingkungan kerja secara bersama-sama berpengaruh terhadap turnover intetion pada karyawan oppo kota bima.

ANOVA $^{b}$

\begin{tabular}{|c|c|c|c|c|c|}
\hline Model & $\begin{array}{l}\text { Sum of } \\
\text { Squares }\end{array}$ & df & $\begin{array}{l}\text { Mean } \\
\text { Square }\end{array}$ & $F$ & Sig. \\
\hline $\begin{array}{l}1 \text { Regres } \\
\text { sion }\end{array}$ & 740.171 & 2 & 370.085 & 34.978 & $.000^{\mathrm{a}}$ \\
\hline $\begin{array}{l}\text { Residu } \\
\text { al }\end{array}$ & 338.572 & 32 & 10.580 & & \\
\hline Total & 1078.743 & 34 & & & \\
\hline \multicolumn{6}{|c|}{$\begin{array}{l}\text { a.Predictors: (Constant), Lingkungan } \\
\text { Kerja, Stres Kerja }\end{array}$} \\
\hline \multicolumn{3}{|c|}{$\begin{array}{l}\text { b. Dependent Variable: } \\
\text { Intetion }\end{array}$} & \multicolumn{2}{|l|}{ Turnover } & \\
\hline
\end{tabular}


6. Uji parsial (Uji t)

ANOVA $^{b}$

\begin{tabular}{|l|l|l|l|l|l|}
\hline Model & $\begin{array}{l}\text { Sum of } \\
\text { Squares }\end{array}$ & Df & $\begin{array}{l}\text { Mean } \\
\text { Square }\end{array}$ & F & $\begin{array}{l}\text { Si } \\
\mathrm{g} .\end{array}$ \\
\hline $\begin{array}{c}1 \text { Regressi } \\
\text { on }\end{array}$ & 740.171 & 2 & $\begin{array}{l}370.08 \\
5\end{array}$ & 34. & $\begin{array}{l}.0 \\
978\end{array}$ \\
$\begin{array}{l}\text { Residual } \\
\mathrm{O}^{\mathrm{a}}\end{array}$ \\
$\begin{array}{c}338.572 \\
\text { Total }\end{array}$ & 32 & 10.580 & & \\
\hline
\end{tabular}

a. Predictors: (Constant), Lingkungan

Kerja, Stres Kerja

b. Dependent Variable: Turnover Intetion

$$
\alpha=5 \%: 2=2,5 \% \text { (uji } 2 \text { sisi) }
$$

dengan (df) n-k-1 atau 35-2-1 = 32. Maka diperoleh $t_{\text {tabel }}$ sebesar 2,036. untuk lebih jelasnya dapat dilihat dalam uraian dibawah ini

a. Variabel stres kerja memiliki nilai thitung $-5,053>\mathrm{t}$ tabel 2,036 yang artinya bahwa Jadi $\mathrm{H}_{0}$ ditolak dan $\mathrm{H}_{a}$ diterima, dimana hipotesis $\mathrm{H}_{a}$ yang menyatakan variabel "stres kerja berpengaruh terhadap turnover intetion" dapat di terima.

b. Variabel lingkungan kerjai kerja memiliki nilai thitung 8,325 < tabel 2,036, yang artinya bahwa Jadi $\mathrm{HO}$ di tolak dan Ha diterima, dimana hipotesis Ho yang menyatakan variabel "lingkungan kerja berpengaruh terhadap turnover interion" dapat di terima.

\section{PENUTUP}

\subsection{Simpulan}

Berdasarkan hasil dari penelitian tentang pengaruh stress kerja dan lingkungan kerja terhadap turnover intention pada karyawan oppo kota bima sesuai dengan tujuan peneitian dapat disimpulkan sebagai berikut:

1. Stress kerja mempunyai pengaruh terhadap lingkungan kerja pada pegawai oppo kota bima dimana nilai t hitung sebesr 8,325 lebih besar dari nilai t tabel sebesar 2,036 dengan nilai signifikan sebesar 0,000 lebih kecil dari 0,05 .

2. Terdapat pengaruh yang signifikan antara variabel stress kerja,lingkungan kerja dan turnover intention bahwa koefisien korelasi $\mathrm{R}$ diperoleh sebesar 0,828.

3. Variabel stress kerja mempengaruhi lingkungan kerja dan turnover intention hanya sebesar $82,8 \%$ terhadap turnover intention sedangkan sisanya $17,2 \%$ dipengaruhi oleh variabel lain yang tidak diteliti dalam penelitian ini.

\subsection{Saran}

Sebagian saran dari konsumen tingkat kinerja kerja bagi para karyawan.

\section{DAFTAR PUSTAKA}

Handoko, T. Hani 2010 manajemen personalia dan sumber daya manusia. Yogyakarta: BPFE

Handoyo, seger. 2001 stress pada masyarakat surabaya. Jurnal insan Media psikologi. Surabaya. Fakultas Psikologi Universitas Airlangga.

Harnoto. 2002. Manajemen sumber daya manusia. Edisi kedua. Jakarta : PT. Prehallindo

Krittner, Robert; dan Kinicki, Angelo 2005 "perilaku organisasi”, Buku 1, Edisi kelima, Salemba Empat, Jakarta.

Mathis \& Jackson (2011). Human Resource Management. USA : South- Western Cengange Learning.

Nitisemito, Alex. 2000 manajemen personalita. Jakarta: Ghalia Indonesia. 
Retno khikmawati (2015) "pengaruh kepuasan kerja, dan lingkungan kerja terhadap Turnover intention pramuniaga di PT circleka Indonesia utama cabang Yogyakarta" skripsi. Universitas Negri Yogyakarta.

Robbins S. P. (2012) Perilaku organisasi (15 ${ }^{\text {th }}$ Edition ed.). Jakarta: PT. Indeks.

Staffelbach, B (2008). Turnover itent. Diploma Thesis. Departement: Stragieund Untrenehmensokonomik. 